\title{
IMPROVED ASSESSMENT OF WHEAT SEEDS VIGOR
}

\author{
Melhor avaliação do vigor de sementes de trigo
}

\author{
Tereza Cristina de Carvalho ${ }^{1}$, Francisco Carlos Krzyzanowski², Osvaldo de Castro Ohlson ${ }^{3}$, Maristela Panobianco ${ }^{4}$
}

\begin{abstract}
The tetrazolium test is widely used for seed vigor assessment of various plant species. For wheat, however, there is no methodology specifically recommended. This study aimed at determining an efficient procedure to evaluate vigor of wheat seeds by this test; besides allowing the establishment of seed quality classes. Thus, four different wheat seed lots were assessed by determining the moisture content and through tests of germination, accelerated aging, and field seedling emergence. The following methodologies were assessed: 1) longitudinal bisection of seed, with subsequent placement of the two halves on filter paper moistened with a $1.0 \%$ tetrazolium solution, at $30^{\circ} \mathrm{C}$, for $2 \mathrm{~h} ; 2$ ) longitudinal bisection, with subsequent immersion of one seed half into a $1.0 \%$ tetrazolium solution, at $30^{\circ} \mathrm{C}$, for $3 \mathrm{~h}$; and 3) longitudinal bisection, with subsequent immersion of one seed half into a $0.075 \%$ tetrazolium solution, at $40^{\circ} \mathrm{C}$, for $2 \mathrm{~h}$. It was concluded that the tetrazolium test is more efficient in evaluating wheat seed vigor when performed with immersion of one half of the seed into a $0.075 \%$ tetrazolium solution $\left(40^{\circ} \mathrm{C}\right.$, for $\left.2 \mathrm{~h}\right)$ or a $0.1 \%$ tetrazolium solution $\left(30^{\circ} \mathrm{C}\right.$, during $3 \mathrm{~h}$ ); allowing to sort seeds into four quality classes.
\end{abstract}

Index terms: Triticum aestivum, physiological quality, viability.

\section{RESUMO}

O teste de tetrazólio é amplamente utilizado para avaliar o vigor de sementes de várias espécies. Porém, para o trigo, não há recomendação de metodologia específica. O objetivo, neste estudo, foi determinar um procedimento eficiente para avaliar o vigor de sementes de trigo, por meio deste teste, permitindo estabelecer classes de qualidade. Foram avaliados quatro diferentes lotes de sementes de trigo, por meio da determinação do grau de umidade e dos testes de germinação, envelhecimento acelerado e emergência de plântulas em campo. Foram testadas as seguintes metodologias: 1) bissecção longitudinal, com disposição das duas metades sobre papel embebido em solução de tetrazólio a $1,0 \%$, a $30^{\circ} \mathrm{C}$, por $2 \mathrm{~h} ; 2$ ) bissecção longitudinal, com imersão de uma das metades em solução de tetrazólio a $0,1 \%$, a $30^{\circ} \mathrm{C}$, por $3 \mathrm{~h}$; e 3 ) bissecção longitudinal, com imersão de uma das metades em solução de tetrazólio a $0,075 \%$, a $40^{\circ} \mathrm{C}$, por $2 \mathrm{~h}$. Concluiu-se que o teste de tetrazólio é mais eficiente quando conduzido mediante imersão de uma das metades da semente em soluções de tetrazólio a $0,075 \%\left(40^{\circ} \mathrm{C}\right.$, por $\left.2 \mathrm{~h}\right)$ ou a $0,1 \%\left(30^{\circ} \mathrm{C}\right.$, por $\left.3 \mathrm{~h}\right)$, permitindo a classificação das sementes em quatro classes de qualidade.

Termos para indexação: Triticum aestivum, qualidade fisiológica, viabilidade.

\section{(Received in august 17, 2012 and approved in october 10, 2012)}

\section{INTRODUCTION}

The wheat occupies the sixth place in the rank of the most cultivated food crops worldwide (FOOD AND AGRICULTURE ORGANIZATION OF THE UNITED NATION-FAOSTAT, 2011) and constitutes the main source of calories for more than 1.5 million people (MANSKE et al., 2001). In Brazil, the annual production of this cereal reaches only 5.9 million metric tons; notwithstanding the national consumption of the grain requires 10.4 million metric tons annually, being thus enormously insufficient to supply the internal market demand (COMPANHIA NACIONALDE ABASTECIMENTO-CONAB, 2011).

To increase wheat production, the adoption of efficient cultural practices in the establishment of the crop in the field such as: the use of high physiological quality seeds (KHAH; ROBERTS; ELLIS, 1989) becomes necessary, once the use of low quality seeds leads to delay of emergence of seedlings in the field, which results in smaller growth of the aerial plant parts as well as smaller growth of the root system (KHAH; ROBERTS; ELLIS, 1989; MEROTTO-JÚNIOR, 1999); low and irregular plant stand in the field (TEKRONY; EGLI, 1991); and lower tolerance to drought (SLOANE; GILL; MCDONALD, 2004; LIAO; PALTA; FILLERY, 2006). These factors may result in grain yield far behind the expected.

The tetrazolium test plays an extremely important role in seed quality control programs, since it is a fast

\footnotetext{
1Universidade Federal do Paraná/UFPR - Departamento de Fitotecnia e Fitossanitarismo - Rua dos Funcionários - 1540 - 80035 -050 - Curitiba - PR Brasil - tcdcarva@gmail.com

${ }^{2}$ Empresa Brasileira de Pesquisa Agropecuária/Embrapa - Centro Nacional de Pesquisa de Soja - Londrina - PR - Brasil

${ }^{3}$ Empresa Paranaense de Classificação de Produtos - Laboratório de Análise de Sementes de Curitiba - Curitiba - PR - Brasil

${ }^{4}$ Universidade Federal do Paraná/UFPR - Departamento de Fitotecnia e Fitossanitarismo - Curitiba - PR - Brasil
} 
method and allows the assessment of viability and vigor of seed lots in less than 24 hours. The test also allows diagnosing the cause of seed deterioration. For soybean seeds, for example, it is possible to detect the damages caused by the drying process, by weathering, by attack of stink bugs, and/or those caused by mechanical damages (FRANÇA- NETO; KRZYZANOWSKI; COSTA, 1998). In relation to the advantages of such test for seeds of wheat deserves emphasis the possibility of its use to assess freshly harvested seeds that would not need to undergo specific treatment to overcome dormancy before physiological quality evaluation; therefore speeding results for the decision taking about the destination of the seed lot.

The tetrazolium test has been successfully used on evaluating vigor of seeds of several plant species, such as: corn (DIAS; BARROS, 1995); soybean (FRANÇA-NETO; KRZYZANOWSKI; COSTA, 1998); watermelon (BHERING; DIAS; BARROS, 2005); tomato (SANTOS; NOVEMBRE; MARCOS FILHO, 2007); and cucumber (LIMA; PINTO; NOVEMBRE, 2010). In the case of wheat seeds, however, the information available on its use for determination of vigor is scarce; and there is no specific methodology recommendation either for its conduction or the establishment of quality classes during assessment.

In this sense, the objective with this study was to determine an efficient methodology for the assessment of vigor of wheat seeds by using the tetrazolium test; with the establishment of quality classes.

\section{MATERIAL AND METHODS}

The research work was carried out in the Seed Analysis Laboratory of the Department of Phytotechnology and Phytosanitary Sciences, Federal University of Paraná, municipality of Curitiba, State of Paraná, Brazil, using four different wheat seed lots of cv. BRS Tangará.

The seed sample of each seed lot was first homogenized into a centrifugal separator, according to criteria established by the Rules for Seed Analysis (RSA) (BRASIL, 2009). After homogenization, the sample was subdivided into four subsamples (replications), of similar weight for each lot, using the same device. Afterwards, the seed were packaged into Kraft paper bags and stored into a controlled environmental chamber $\left(14^{\circ} \mathrm{C} ; 60 \% \mathrm{RH}\right)$ during all the experimental period, aiming at minimizing deterioration intensity. performed:

The following assessments were afterwards
Moisture content determination: this test was performed by the oven method at $105 \pm 3^{\circ} \mathrm{C}$, for $24 \mathrm{~h}$, using two subsamples of $5.0 \mathrm{~g}$ each, for each replication (BRASIL, 2009). Results were expressed in percentage mean for each seed lot, in wet basis.

Germination test: for each replication, two subsamples of 50 seeds each were taken, thus totaling eight replications per seed lot. The seeds of each replication were then evenly distributed on top of two sheets of paper towels, covered with another sheet of the same paper, all previously moistened with distilled $\mathrm{H}_{2} \mathrm{O}$ in a proportion equivalent to 2.5 times the mass of the dry substrate, and made into rolls. Immediately after, these rolls were placed into a seed germinator, at $20^{\circ} \mathrm{C}$, under constant light. The counting of seedling was performed at the fifth day after sowing, according to RSA (BRASIL, 2009). Results were expressed as the mean percentage of normal seedlings for each seed lot.

Accelerated aging: for this test, the procedure recommended by por Ohlson et al. (2010) was used. For this, the test was conducted using $11 \mathrm{~cm} \mathrm{x} 11 \mathrm{~cm} \times 3.5$ $\mathrm{cm}$ transparent plastic germination boxes (gerbox) containing $40 \mathrm{ml}$ of distilled $\mathrm{H}_{2} \mathrm{O}$ at the bottom. An aluminum screen was then fixed at the upper edge of each gerbox where seed of each subsample were uniformly distributed on a single layer. The sets (gerbox + seeds) were subsequently placed into a controlled environmental chamber (at $43^{\circ} \mathrm{C}$ and $100 \% \mathrm{RH}$ ) during $48 \mathrm{~h}$. After that period, the seeds of each gerbox were subjected to germination test as previously described in the item 2. Determination of moisture content was performed, as already described in the item 1, before and after the accelerated aging procedure aiming at assessing the uniformity of the test conditions. Results were expressed as the mean percentage of normal seedlings for each seed lot.

Emergence of seedlings in the field: this test was carried out within an experimental area of the Department of Phytotechnology and Phytosanitary Sciences, Federal University of Paraná, in September, 2011. For each seed lot, four replications of 100 seeds each were taken. These seeds were sowed in small plots, with soil without fertility correction, into five rows with $3.0 \mathrm{~cm}$ deep and $40 \mathrm{~cm}$ long, with $5.0 \mathrm{~cm}$ interspaces and $2.0 \mathrm{~cm}$ between seeds within the row, with artificial irrigation at each three days (when natural precipitation had not occurred). The evaluations were performed at the fourteenth day after sowing by counting the number of normal seedlings emerged; and the results were 
expressed as the mean percentage of normal seedling for each seed lot.

Tetrazolium test: for this test, four replications of 55 seeds each were withdrawn from each seed lot. During the assessment, however, only 50 seeds per replication were computed. The procedure of using an additional $10 \%$ of seeds was adopted as safety; in case of problems occurrence in the hydration of seeds during the preconditioning step. The seeds were previously moisturized between one sheet of paper towels, moistened with distilled water in a volume equivalent to 2.5 times the mass of dry substrate, at $20^{\circ} \mathrm{C}$, during $18 \mathrm{~h}$ (BRASIL, 2009). The following treatments were then performed:

a) longitudinal cut, bisecting the seed along the embryo and endosperm with the aid of a razor blade; and then placing the two halves of the seed on top of filter paper moistened with a $1.0 \%$ solution of 2,3,5 triphenyl tetrazolium chloride (INTERNATIONAL SEED TESTING ASSOCIATION-ISTA, 2008) in a volume equivalent to 2.5 times the mass of the dry substrate, in the dark, during $2 \mathrm{~h}$ (BRASIL, 2009);

b) longitudinal cut, bisecting the seed along the embryo and endosperm with the aid of a razor blade; and then immersing one half of the seed into a $3 \mathrm{ml}$ of a $0.075 \%$ or $0.1 \%$ of 2,3,5 triphenyl tetrazolium chloride solutions (Dias; Barros, 1995), into $50 \mathrm{ml}$ capacity plastic cups, at $30^{\circ}$ $\mathrm{C}$ (for $3 \mathrm{~h}$ ) or at $40^{\circ} \mathrm{C}$ (for $2 \mathrm{~h}$ ), respectively, in the dark.

After each staining period, the seeds were maintained on top of the filter paper (staining on paper) or immersed into water (staining by immersion), under refrigeration (varying from $5^{\circ} \mathrm{C}$ to $10^{\circ} \mathrm{C}$ ) until assessment, which was performed at the same day of staining,

Based on the vital structures of wheat seeds (coleoptile, plumule, mesocotyl, radicle, coleorhiza, and the central region of the scutellum) and on the classes defined for the assessment of corn seeds by the tetrazolium test (DIAS; BARROS, 1995), classes of vigor for wheat seeds by the tetrazolium test were proposed.

Data obtained in the tests, except for moisture content determination, were analyzed using a completely randomized experimental design, with eight replications, and the ANOVA performed separately for each test performed. Data obtained by the tetrazolium test were analyzed with four replications. It was also determined the Spearman correlation coefficient between data obtained on seedling emergence in the field and on the tetrazolium test data. Means were compared by the Tukey test at $1 \%$ probability $(\mathrm{p} \leq 0,01)$.

\section{RESULTS AND DISCUSSION}

The moisture content of seeds for the four seed lots were similar and did not present statistically significant differences between each other, showing a variation of only $0.6 \%$ (Table 1 ). Such fact is important, since demonstrates the reliability of the evaluations and the feasibility in the achievement of consistent results. By the germination test (Table 1) it was possible to sort the seed lots 1, 2, and 3 as of the highest quality; and the seed lot 4 was the one with the lowest performance. Nevertheless all the four seed lots have presented germination above the standards established for seed commercialization. In the accelerated aging test it was possible to detect statistically significant difference only for the seed lot 4, in a similar way to what was obtained in the test of germination (Table 1).

Differently, for emergence of seedlings in the field (Table 1) statistically significant differences on the levels of vigor were detected among the four seed lots studied: the seed lot 1 has presented the highest quality; the seed lots 2 and 3 had an intermediary behavior; while the seed lot 4 presented the lowest quality.

Table 1 - Moisture content of seeds and percentage of wheat seedlings assessed by tests of germination, accelerated aging and seedling emergence in the field, obtained from four different wheat seed lots, cv. BRS Tangará.

\begin{tabular}{ccccc}
\hline Seed lots & Moisture content & Germination & Accelerated aging & Seedling emergence in the field \\
\hline 1 & 12.9 & $96 \mathrm{a}^{*}$ & $90 \mathrm{a}^{*}$ & $83 \mathrm{a}^{*}$ \\
2 & 12.5 & $93 \mathrm{a}$ & $89 \mathrm{a}$ & $76 \mathrm{ab}$ \\
3 & 12.3 & $93 \mathrm{a}$ & $86 \mathrm{a}$ & $69 \mathrm{bc}$ \\
4 & 12.6 & $80 \mathrm{~b}$ & $62 \mathrm{~b}$ & $65 \mathrm{c}$ \\
\hline $\mathrm{CV}(\%)$ & - & 3.8 & 5.3 & 5.9 \\
\hline
\end{tabular}

* Means followed by the same letter in the column are not statistically different between each other by the Tukey test at $1 \%$ probability $(\mathrm{p} \leq 0.01)$.

Ciênc. agrotec., Lavras, v. 36, n. 6, p. 608-614, nov./dez., 2012 
To obtain the results of the tetrazolium test, the seeds were individually assessed according to the established criteria, which are shown on table 2 . As viable seeds (viability) were computed those seeds included in the classes 1 and 2; and as potentially vigorous (vigor) only those seeds included in the class 1 . In addition to these classes, some seeds were sorted as non-viable (class 3) or as dead seeds (class 4). On the figure 1, the classes established within this study of vigor for wheat seeds by the tetrazolium test are shown.
The viability of the wheat seeds, assessed by the tetrazolium test, is presented on table 3 (upper section). By analyzing data computed, it can be observed that the use of the tetrazolium solution at $0.075 \%$ has allowed sorting the seed lots into three quality levels: high quality (lot 1); intermediary quality (lots 2 and 3); and low quality (lot 4). For results obtained with the tetrazolium solution at $0.1 \%$ and $1.0 \%$, the seed lots 1 , 2 , and 3 were sorted in the category of high viability; and the seed lot 4 in the category of low viability, i.e., results similar to those obtained by the germination test (Table 1).

Table 2 - Classes of vigor and viability of wheat seeds obtained through assessment by the tetrazolium test.

\begin{tabular}{cl}
\hline Class of seeds & \multicolumn{1}{c}{ Description } \\
\hline $\begin{array}{c}\text { 1- viable and } \\
\text { vigorous }\end{array}$ & $\begin{array}{l}\text { Perfect seeds, displaying a shiny pinkish color, superficial, uniform and without lesions in the } \\
\text { embryo (Figure 1A); or with the embryo with shiny pink color, with small areas or dots with } \\
\text { more intense hue (Figure 1B); or with small deteriorated dots or dead tissues on the extremities } \\
\text { of the scutellum, but without reaching the vital region (Figure 1C). }\end{array}$ \\
\hline $\begin{array}{l}\text { Seeds with damages reaching the radicle, but with the region of the mesocotyl (seminal roots) } \\
\text { non-vigorous }\end{array}$ & $\begin{array}{l}\text { intact (Figures 1D, 1E and 1F); seeds with intense and profound red coloration in the embryo } \\
\text { region, indicating higher deterioration of the damaged tissue (Figure 1G); seeds presenting } \\
\text { damages or discolored regions on larger areas of the scutellum, since these areas do not reach } \\
\text { the vital regions of the embryo (Figure 1H). }\end{array}$ \\
\hline $3-$ non-viable & $\begin{array}{l}\text { Seeds with intense red coloration of the embryo with discolored areas in the plumule, in addition } \\
\text { to the regions of the coleoptile and radicle (Figure 1I); with discolored areas on the plumule and } \\
\text { the radicle region (Figure 1J); and with discolored areas in the coleoptile plus the radicle region } \\
\text { and part of the scutellum (Figures 1L and 1M); seeds with damages, or discolored regions, in the } \\
\text { mesocotyl and part of the scutellum (Figures 1N and 1O); seeds that present damages, or } \\
\text { discolored regions, in the central portion of the scutellum (Figure 1P). }\end{array}$ \\
\hline $4-$ dead & \begin{tabular}{l} 
Embryo totally grayish (Figures 1Q and 1R). \\
\hline
\end{tabular}
\end{tabular}
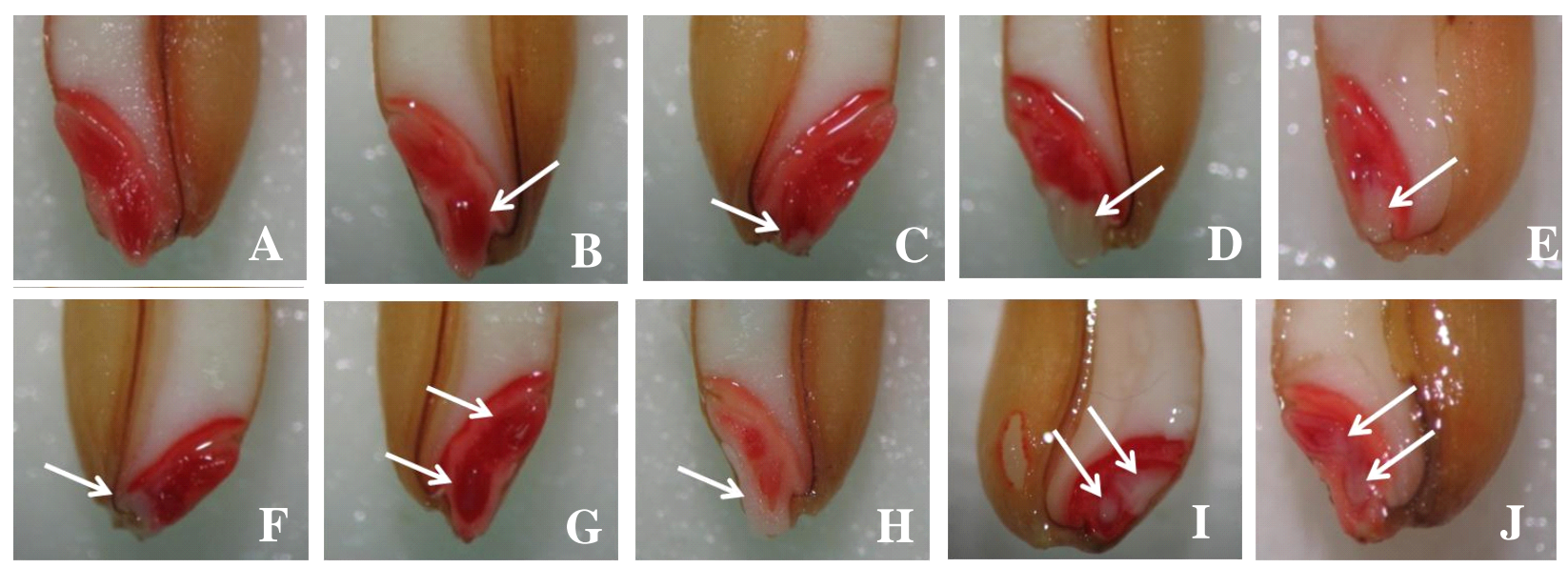

Figure 1 - Classification of quality of wheat seeds established by the tetrazolium test: class 1 (A, B, and C); class 2 (D, E, F, G, and H); class 3 (I, J, L, M, N, O, and P); class 4 (Q and R); and seeds that are beginning to germinate during the hydration procedure $(\mathrm{S})$. 

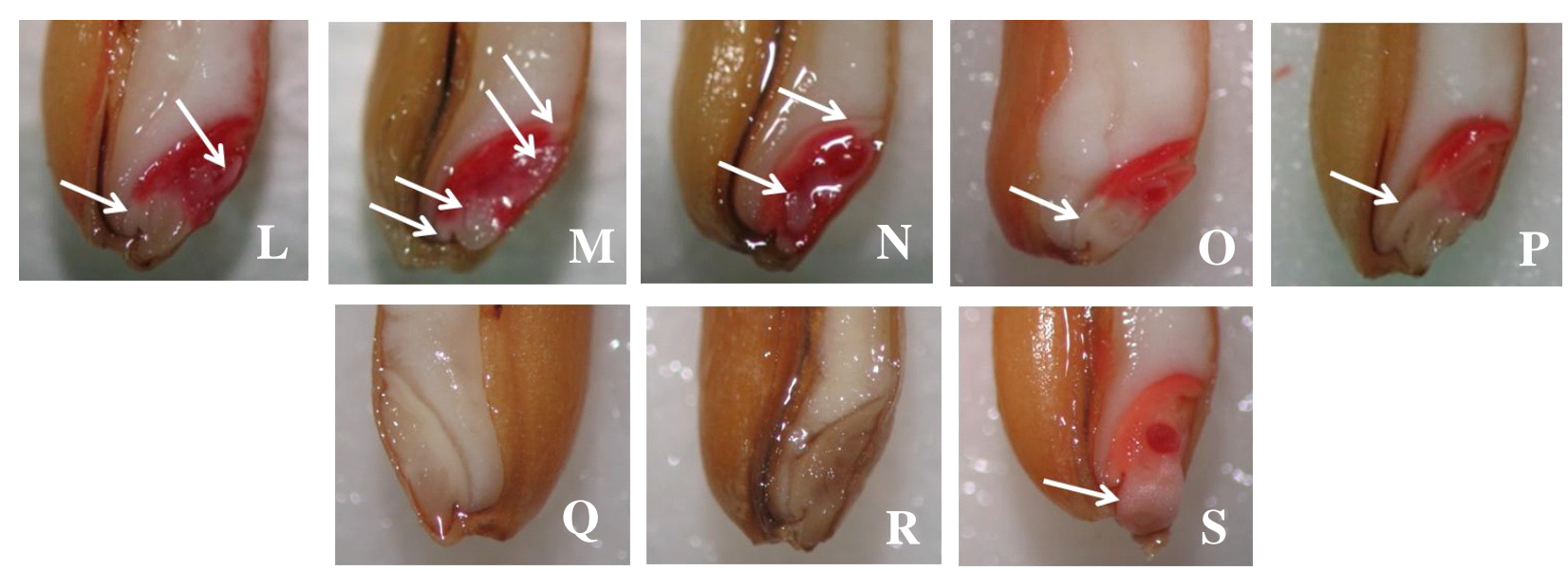

Figure 1 - Continued...

Table 3 - Viability (upper part) and vigor (lower part) of seeds of four wheat seed lots, cv. BRS Tangará, obtained by the tetrazolium test carried out with different procedures.

\begin{tabular}{|c|c|c|c|}
\hline \multirow{3}{*}{ Seed lots } & \multicolumn{3}{|c|}{ Viability } \\
\hline & \multicolumn{3}{|c|}{ Concentration of tetrazolium solution } \\
\hline & $0.075 \%$ & $0.1 \%$ & $1.0 \%$ \\
\hline & \multicolumn{3}{|c|}{ 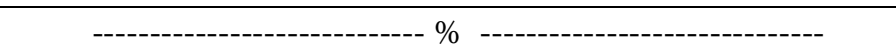 } \\
\hline 1 & $93 a^{*}$ & $96 \mathrm{a}^{*}$ & $96 a^{*}$ \\
\hline 2 & $89 \mathrm{ab}$ & $95 \mathrm{a}$ & $94 \mathrm{a}$ \\
\hline 3 & $90 \mathrm{ab}$ & $92 \mathrm{a}$ & $92 \mathrm{a}$ \\
\hline 4 & $81 \mathrm{~b}$ & $81 \mathrm{~b}$ & $78 \mathrm{~b}$ \\
\hline $\mathrm{CV}(\%)$ & 5.6 & 2.4 & 2.9 \\
\hline \multirow{3}{*}{ Seed lots } & \multicolumn{3}{|c|}{ Vigor } \\
\hline & \multicolumn{3}{|c|}{ Concentration of tetrazolium solution } \\
\hline & $0.075 \%$ & $0.1 \%$ & $1.0 \%$ \\
\hline & \multicolumn{3}{|c|}{----10 } \\
\hline 1 & $51 \mathrm{a}^{*}$ & $40 \mathrm{a}^{*}$ & $57 a^{*}$ \\
\hline 2 & $46 \mathrm{ab}$ & $36 \mathrm{~b}$ & $46 \mathrm{~b}$ \\
\hline 3 & $42 \mathrm{bc}$ & $32 \mathrm{c}$ & $47 \mathrm{~b}$ \\
\hline 4 & $35 \mathrm{c}$ & $19 \mathrm{~d}$ & $9 \mathrm{c}$ \\
\hline $\mathrm{CV}(\%)$ & 7.9 & 5.1 & 5.4 \\
\hline C.C. Spearman & $1.00 * *$ & $1.00 * *$ & $0.80^{\text {n.s. }}$ \\
\hline
\end{tabular}

* Means followed by the same letter in the column are not statistically different between each other by the Tukey test $(\mathrm{p} \leq 0.01)$.

C.C.Spearman: ** significant at $1 \%$ probability, by the "t" test; ${ }^{\text {n.s. }}$ non-significant.

For data on vigor, also assessed by the tetrazolium test (Table 3, lower section) there was a separation of the seed lots similar to that obtained for seedling emergence in the field, when tetrazolium solutions at $0.075 \%$ and $0.1 \%$ were used; showing highly significant values (1.00**). With this procedure occurred a very distinct staining of the seed tissues (Figure 1A), thus allowing visualizing the tissues of the embryo, which have acquired a shiny pinkish color. 
When the tetrazolium solution at $1.0 \%$ concentration was used (Table 3 , lower sector) the results did not present significant correlation with seedling emergence in the field (Table 1). This probably occurred because the $1.0 \%$ tetrazolium concentration influenced the staining process of the seeds, once the embryo tissues, instead of acquiring the shiny pinkish color, presented an intense red color hue (similar to color of damaged tissues). Since the assessment is based on the color of embryo tissues, the distinction of seed belonging to class 1 (viable and vigorous seeds) from those belonging to class 2 (viable and non-vigorous) became difficult. Therefore, by the results obtained it was verified that the tetrazolium concentrations of $0.075 \%$ and $0.1 \%$ were the most efficient in determining wheat seed vigor.

It is recommended that during the process of preconditioning of wheat seeds for the tetrazolium test, the seeds whose germination process have already started (with emission of the primary root), as illustrated on Figure $1 \mathrm{~S}$, should not be used. This is due to the fact that the distinction of the structures of the embryo such as the radicle, the coleorhiza, and the lower part of the scutellum becomes difficult, thus preventing the correct characterization of vigor of the seed.

\section{CONCLUSIONS}

The most effective methodologies to evaluate seed vigor are preconditioning of the seeds between moistened paper towels for $18 \mathrm{~h}$, at $20^{\circ} \mathrm{C}$ and then perform the staining of one half of seed by immersion into a $0.075 \%$ tetrazolium solution, at $40^{\circ} \mathrm{C}$, during two hours or into a $0.1 \%$ tetrazolium solution, at $30^{\circ} \mathrm{C}$, during three hours.

The tetrazolium test, when applied to assess wheat seed vigor, allows the sorting of these seeds into four quality classes.

\section{REFERENCES}

BHERING, M.C.; DIAS, D.C.F.S.; BARROS, D.I. Adequação da metodologia do teste de tetrazólio para avaliação da qualidade fisiológica de sementes de melancia. Revista Brasileira de Sementes, Pelotas, v.27, n.1, p.176-182, jun. 2005.

BRASIL. Ministério da Agricultura, Pecuária e Abastecimento. Regras para análise de sementes. Secretaria de Defesa Agropecuária. Mapa/ACS, Brasília, DF, Brasil. 2009. 399p.
COMPANHIA NACIONAL DE ABASTECIEMNTOCONAB. Acompanhamento da Safra Brasileira de Grãos 2010/2011 - Quarto Levantamento - Janeiro/ 2011. Brasília. 2011. 40p.

\section{DIAS, M.C.L.L.; BARROS, A.S.R. Avaliação da} qualidade de sementes de milho. IAPAR, Circular 88, Londrina, PR, Brasil, p.42, 1995.

\section{FOOD AND AGRICULTURE ORGANIZATION OF} THE UNITED NATIONS-FAOSTAT. Top production - Wheat. 2008. Disponível em: <http://

faostat.fao.org/site/339/default.aspx $>$. Acesso em: 23 nov. 2011.

FRANÇA NETO, J.B.; KRZYZANOWSKI, F.C.; COSTA, N.P. O teste de tetrazólio em sementes de soja. EMBRAPA-CNPSo Documentos 116, Londrina, PR, Brasil, 72 p. 1998.

INTERNATIONAL SEED TESTING ASSOCIATION-

ISTA. Biochemical test for viability: the topographical tetrazolium test. In: International rules for seed testing. eds. Bassersdorf, Switzerland. p.1-30, 2008.

KHAH, E. M.; ROBERTS, E. H.; ELLIS, R. H. Effects of seed ageing on growth and yield of spring wheat at different plant-population densities. Field Crops Research, Bucks, v.20, p.175-190, 1989.

LIAO, M.; PALTA, J.A.; FILLERY, I.R.P. Root characteristics of vigorous wheat improve early nitrogen uptake. Australian Journal of Agricultural Research, Canberra, v.57, p.1097-1107, set. 2006.

LIMA, L.B.; PINTO, T.F.L.; NOVEMBRE, A.D.L.C. Avaliação da viabilidade e do vigor de sementes de pepino pelo teste de tetrazólio. Revista Brasileira de sementes, Londrina, v.32, n.1, p.60-68, 2010.

MANSKE, G.G.B. et al. Importance of P uptake efficiency versus $P$ utilization for wheat yield in acid and calcareous soils in Mexico. European Journal of Agronomy, Bonn, v.14, p.261-274, jul. 2001.

MEROTTO JÚNIOR, A. et al. A desuniformidade de emergência reduz o rendimento de grãos de milho. Ciência Rural, Santa Maria, v.29, n.4, p.595-601, 1999. 
OHLSON, O.C. et al. Teste de envelhecimento acelerado em sementes de trigo. Revista Brasileira de Sementes, Londrina, v.32, n.4, p.118-124, 2010.

SANTOS, M.A.O.; NOVEMBRE, A.D.L.C.; MARCOS FILHO, J. Tetrazolium test to assess viability and vigour of tomato seeds. Seed Science and Technology, Zurich, v.35, n.1, p.213-223, abr. 2007.
SLOANE, D.H.G; GILL, GS.; MCDONALD, GK. The impact of agronomic manipulation of early vigour in wheat on growth and yield in South Australia.

Australian Journal of Agricultural Research, Canberra, v.55, p.645-654, jul. 2004.

TEKRONY, D.M.; EGLI, D. B. Relationship of seed vigor to crop yield: a review. Crop Science, Madison, v.31, p.816-822, mai. 1991. 